\title{
The Effect of Literature Circles on Reading Comprehension Skills *
}

\author{
Süleyman AVCI $^{* *} \quad$ Nurdan BAYSAL $^{* * *} \quad$ Mehtap GÜL $^{* * * *}$ Arzu \\ YÜKSEL $^{* * * * *}$
}

Received: 19 April 2012

Accepted: 18 June 2013

\begin{abstract}
This study aims at investigating the effect of literature circles on reading comprehension skills of fifth graders. Pre-test - post-test control group design was used in this study conducted with two fifth grade classrooms in a primary school in Maltepe, Istanbul. There were 34 students in the experimental group and 33 students in the control group. Data were collected through the "Reading Comprehension Scale". Results indicated that post-test scores of the experimental group increased more than those of the control group. The level of this increase was higher in the group with poor reading comprehension skills.
\end{abstract}

Keywords: literature circles, reading comprehension skills, teaching method

\section{Extended Abstract}

Purpose and Significance: Literature circles is a teaching method in which students discuss parts they read in groups formed according to the books chosen at certain intervals. It is a combination of individual reading practice and collaborative learning method. The method is used particularly for acquisitions such as reading habits, reading comprehension, self-expression, verbal language and social interaction. The implementation of this method begins with teacher's determining books to be read. The number of books should mostly be six due to the number of students in each group. Then, books determined by the teacher are selected by students and students selecting the same book form a group. In the first meeting, students split books into appropriate number of parts, determine meeting dates, decide on projects on books and share roles. Common roles are interrogator, group leader, connector and artist, summarizer, researcher, word-hunter and stage editor. The following group meetings are arranged on roles played. Group members join each meeting after they read related parts and do their tasks. After reading comes to an end, each group presents their books to other groups via projects done. Type of books, page number of books, the number of meetings, roles and types of projects vary according to grade level. Although the method is quite effective for gaining reading habits and reading comprehension skills, it just has been used in Turkey. Therefore, it is necessary to evaluate its appropriateness to different grade levels, different groups and courses and to examine its effects on

\footnotetext{
*Part of this study was presented at the First International Congress on Curriculum and Instruction.

${ }^{* *}$ Corresponding Author: Assist. Prof. Dr., Marmara University, Istanbul, suleyman.avci@marmara.edu.tr

***Assoc. Prof. Dr., Marmara University, Istanbul, nurdanbaysal@hotmail.com

*****Teacher, Ministry of Education, Istanbul, mehtapgulerdogan@hotmail.com

MSc, Europe College, Istanbul, arzu.yuksel@avrupakoleji.com.tr
} 
students in terms of different variables. This study aims at investigating the effect of literature circles on reading comprehension skills of fifth graders.

Methods: Pre-test - post-test control group design was used in this study conducted with two fifth grade classrooms in a primary school in Maltepe, Istanbul. There were 34 students in the experimental group and 33 students in the control group. The experimental group of the study was preferred because the teacher accepting to participate in this study was the teacher of that classroom. One of the classrooms with similar characteristics to the experimental group was preferred as the control group. Data were collected through the "Reading Comprehension Scale". The scale consists of 20 multiple-choice questions measuring reading comprehension. According to pre-test administration of the scale, reading comprehension skills of both groups (Mexperimental $=$ 10.9, Mcontrol $=12.7)$ were found similar $(p>0.05)$. Within the scope of the study, literature circles were only used in the experimental group. Six books with different themes were selected by the researchers for intervention. They are Ünlüler de Çocuktu (biography), Çatalhöyük Öyküleri (historical), On Beş Türk Masalı (tale), Uzaylılar Geliyor (science-fiction), Süper Futbolcular için Başlama Düdüğü Çalıyor (sports), Gözlerinde Güneş Var (memoir). Books were introduced to the classroom and students were asked to make a choice. According to students' choices, five groups with six people and one group with five people were formed. In their first meeting, groups decided on the number of pages to be read for each meeting, tasks to be performed, people to perform these tasks as well as task order, and type of the project. After groups had been formed, teacher did practice with a short story in order to show students which roles should be played and how groups should discuss. Students met in a course hour on Mondays and Thursdays each week. In these meetings, they shared the works they did in accordance with their tasks and discussed about the part read. As it was planned, the intervention lasted in three weeks. In the fourth week, groups presented their books to whole classroom within three course hours. While one group preferred puppet theater, one group preferred poem, one group preferred PowerPoint presentation and one group preferred visual presentation, two groups preferred role-play. The intervention came to an end with presentations that totally lasted in four weeks. Two days after presentations, the Reading Comprehension Scale was administered as the post-test. The post-test could not be administered to three students in the experimental group and eight students in the control group because they were absent at that time of the study. Independent-samples $t$ test and Wilcoxon signed-rank test were employed to analyze the data.

Results: Results indicated that the pre-test score of the experimental group was 10.9 while the post-test score of this group was 11.9. This increase was found statistically significant $(p<0.05)$. The pre-test score was 12.7 in the control group while the post-test score of this group was 13.5 , but the difference was not statistically significant $(p>0.05)$. Students in the experimental group were split into two groups in terms of their pre-test scores as poor-skilled and strong-skilled. Increases in post-test scores compared to pre- 
test scores were reanalyzed again. Results showed that average pre-test score of poorskilled students increased from 6.5 to 8.7 while average score of strong-skilled students remained the same (13.9). The increase in scores of poor-skilled students was statistically significant $(p<0.05)$.

Discussion and Conclusions: Regarding the findings, it can be said that literature circles is an effective way of getting fifth graders to gain reading comprehension skills. If such an increase is achieved with only one reading, it can be thought that especially poor-skilled students will reach the level of strong-skilled ones if the method is constantly used. All in all, it can be said that literature circles might be used in order to get fifth graders to gain strong reading comprehension skills. Also, use of literature circles at different grade levels might further be investigated. 


\title{
Okuma Çemberi Yönteminin Okuduğunu Anlama Becerisine Etkisi ${ }^{*}$
}

\author{
Süleyman AVCI ${ }^{* *}$ Nurdan BAYSAL ${ }^{* * *}$ Mehtap GÜL $^{* * * *}$ Arzu YÜKSEL ${ }^{* * * * *}$
}

Makale Gönderme Tarihi: 19 Nisan 2012

Makale Kabul Tarihi: 18 Haziran 2013

ÖZET: Bu araştırmanın amacı, okuma çemberinin ilköğretim beşinci sınıf öğrencilerinin okuduğunu anlama becerilerine etkisini belirlemektir. Araştırmada ön-test - son-test kontrol gruplu deneysel desen kullanılmıştır. Araştırma İstanbul ili Maltepe ilçesinde bir ilköğretim okulunun 67 beşinci sınıf öğrencisi ile yürütülmüştür. Bu öğrencilerin 34'ü deney, 33'ü ise kontrol grubundadır. Veriler, “Okuduğunu Anlama Ölçeği” kullanılarak elde edilmiştir. Ön-test ve son-test uygulama sonuçlarına göre deney grubunda okuduğunu anlama becerisi, kontrol grubuna göre, anlamlı düzeyde daha fazla artış göstermiştir. Bu artış, deney öncesi okuduğunu anlama becerisi düşük olanlarda, yüksek olanlara göre daha fazla gerçekleşmiştir.

Anahtar sözcükler: okuma çemberi, okuduğunu anlama becerisi, öğretim yöntemi.

\section{Giriș}

Okuma çemberi, öğrencilerin seçtikleri kitaplara göre oluşturulan gruplarda, okudukları bölümleri belirli aralıklarla tartıştıkları bir öğretim yöntemidir (Daniels, 2002). Yöntem, özellikle okuma alışkanlığı, okuduğunu anlama, kendini ifade etme, sözel dil, sosyal etkileşim gibi becerileri kazandırmak amacıyla kullanılmaktadır (Alwood, 2000; Blum, Lipsett, \& Yocom, 2002; Burda, 2000; Chiang \& Huang, 2005; Pitton, 2005; Rutherford, Carter, Hillmer, Kramer, \& Parker, 2009; Stabile, 2009). Okuma çemberi, kitap kulübü uygulamasını okul ortamına uyarlamak isteyen öğretmenlerin ürünüdür. Kitap kulübü, yetişkinler arasında aynı kitabın okunduğu ve ardından üzerine tartışıldığı bir uygulamadır. Okuma çemberini ilk uygulayan (1982 yılında) Karen Smith, bu ismi ilk kullananlar ise (1984 y1lında) Kathy Short ve Gloria Kaufman olmuştur (Daniels, 2002).

Okuma çemberi, 30 yıla yakın bir süredir yaygın olarak kullanılmaktadır. Yöntemin bu kadar fazla kabul görmesinin sebeplerinden biri, yapılandırmacılık (okuyucu tepkisi teorisi, şema teorisi ve araştırmaya dayalı öğrenme teorisi) ve sosyokültürel teori gibi iki temel kurama dayanmasıdır (Hsu, 2004; Tracey \& Morrow, 2006). Okuyucu tepkisi teorisine (Rosenblatt, 1978) göre, birey kitabı kendi yaşantısına göre anlamlandırdığı için okunan kitaptan herkes farklı şeyler anlar ve kazanır. Okuma çemberinde, yapılan tartışma toplantıları aracılığıyla, herkes kitapla ilgili kazanımlarını birbiriyle paylaşmaktadır. Böylece öğrenciler, farklı bakış açıları hakkında bilgi sahibi olurlar (Aktaran: Tracey \& Morrow, 2006). Şema teorisine göre ise, geçmiş yaşantıs1 zengin olanların bir kitabı anlamaları, fakir olanlardan daha kolay olmaktadır. Okuma çemberinde öğrenciler kitapla ilgili duygu ve düşüncelerini paylaşarak birbirinin şemalarının gelişimine katkıda bulunmaktadır. Araştırmaya dayalı öğrenme (inquiry

\footnotetext{
*Bu makalenin bir kısmı I. Uluslararası Eğitim Programları ve Öğretim Kongresinde bildiri olarak sunulmuştur.

** Sorumlu Yazar: Yrd. Doç. Dr., Marmara Üniversitesi, İstanbul, suleyman.avci@marmara.edu.tr

**** Doç. Dr., Marmara Üniversitesi, İstanbul, nurdanbaysal@hotmail.com

**** Öğretmen, Milli Eğitim Bakanlığı, İstanbul, mehtapgulerdogan@hotmail.com

******Uzman, Avrupa Koleji, İstanbul, arzu.yuksel@avrupakoleji.com.tr
} 
learning), öğrencilerin küçük gruplar hâlinde bir problemin çözümüne yönelik yaptıkları etkinlikleri içermektedir. Kuramın okuma çemberine katkısı, öğrencilerin grup çalışması yapmaları ve öğretim sürecinde aktif olmalarıdır (Tracey \& Morrow, 2006). Okuma çemberinin dayandığı son kuramsal temel olan sosyo-kültürel teoriye göre, öğrenciler birbirinden öğrenmektedir. Okuma çemberinde, farklı kültürlerden gelen öğrenciler deneyimlerini paylaşarak, birbirlerinin öğrenmesini zenginleştirmektedirler (Hsu, 2004; Tracey \& Morrow, 2006).

Yöntem, bireysel okuma uygulaması ile işbirliğine dayalı öğrenme yönteminin birleştirilmiş hâlidir (Tracey \& Morrow, 2006). Okuma çemberi, hem düşük hem de yüksek yetenekli öğrencilere okumaları için zaman tanıması ve öğrencilerin kendilerine uygun olan kitabı seçmelerine izin vermesi açısından farklılaştırılmış bir öğretim yöntemidir (Tomlinson \& Strickland, 2005).

Okuma çemberinin uygulama süreci, kitap seçimi ile başlamaktadır. Öğretmen seçim yaparken; ulaşabilecek kitap sayısı, öğrenci düzeyi, kitabın öğrencilerin kültürel düzeyine uygunluğu, kitabın öğrenci için faydalı olması, öğrenci ilgisi gibi birçok değişkeni göz önünde bulundurur (Carpinelli, 2006). Kitaplar belirlendikten sonra teknik hakkında öğrenciler bilgilendirilir. Sonrasında kitaplar öğrencilere tanıtılır ve içlerinden kendilerine uygun olanı seçmeleri sağlanır (Daniels, 2002). Seçimlere göre de iki-altı arası öğrenciden oluşan gruplar oluşturulur (Brabham \& Villaume, 2000). Gruplar ilk toplantısında, günde kaç sayfa okuyacaklarına, kimlerin hangi rolleri alacağına, hangi projeyi seçeceklerine karar verirler ve bunları ilgili formlara işlerler. Bundan sonraki toplantılarda okunan bölümler tartışılır. Okuma çemberinde düzenli toplantılar önem taşımaktadır. Öğretmen toplantı günü ve saatiyle ilgili kurallar koymalıdır. Toplantılarda tartışmanın hangi başlıklar altında olacağı öğrenciler tarafından belirlenir. Tartışmalar, sorgulayıcı rolündeki öğrencinin kontrolünde gerçekleşir. Kitap okuma işi bittikten sonra, gruplar okudukları kitapla ilgili sınıfa sunmak üzere özetleme, drama, tiyatro, eksik bölüm yazımı gibi projeler hazırlarlar (Moeller \& Moeller, 2007). Tüm bu süreçlerde öğretmenin rolü rehberliktir (Alwood, 2000; Short, Kaufman, Kaser, Kahn, \& Crawford, 1999).

Okuma çemberinde önemli noktalardan biri de rollerin belirlenmesidir. Roller, özellikle grup tartışmalarını istenen çerçevede yürütmeyi ve yönlendirmeyi sağlamak için belirlenir. Bir öğrencinin tüm rolleri üstlenmesi için her toplantıda roller değişmelidir (Daniels, 1994; Straits, 2007; Tracey \& Morrov, 2006). Yaygın olarak kullanılan roller; sorgulayıcı, bölüm lideri, bağ kurucu ve sanatçı, özetleyici, araştırmac1, sözcük avcısı, sahne düzenleyici, karakter ustası, gözlemci ve film eleştirmenidir (Daniels, 2002). Her öğrenci grup toplantısında göreviyle ilgili bulgularını ve yaptıklarını arkadaşlarıyla paylaşır (DaLie, 2001; Moeller \& Moeller, 2007).

Okuma çemberinde otantik değerlendirmeden yararlanılmalıdır. $\mathrm{Bu}$ amaçla, portfolyo, rubrik, gözlem formları, akran değerlendirmesi ve öz değerlendirme formları kullanılabilir. Bunlara ek olarak, uygulama sürecini sistemli hâle getirmek amaciyla kullanılan formlar da birer değerlendirme aracı olarak ele alınabilir. Değerlendirme için; 
öğrencilerin günlük hazırlıkları, grup toplantılarındaki performansları ve final projeleri kullanılmalıdır (Daniels, 2003).

Yöntem, okuma alışkanlığı kazandırmada (Burda, 2000; Chiang \& Huang, 2005) ve okumayı sevdirmede (Culli, 2002; Olsen, 2007; Pitton, 2005; Rutherford ve diğerleri, 2009) oldukça etkilidir. Ayrıca, öğrencilerin okuma (Blum ve diğerleri, 2002; Stabile, 2009) ve okuduğunu anlama becerilerinin (Avcı \& Yüksel, 2011; Mizerka, 1999) gelişmesini de sağlamaktadır. Süreci başardığını gören öğrencilerin okuma ve anladığını paylaşmaya yönelik özgüven düzeyleri yükselmektedir (Culli, 2002; Olsen, 2007). Bir yıl boyunca yöntemin uygulandığı bir sınıfta öğrenciler; ayda bir olmak üzere en az altı kitap okur, bu sayının birkaç katı kitabın özetini dinler. Böylece öğrenciler dünyayı tanıma firsatı sağlamış olurlar (Burda, 2000). Yöntem, bir grup etkinliği olduğundan öğrencilere; diğer öğrencilerle iletişim kurma (Alwood, 2000), grup önünde konuşma (Stabile, 2009), bölmeden dinleme, dinlerken göz temasını sürdürme (Culli, 2002), duygularını ve fikrini ifade etme, grupla-ekiple çalışma (Alwood, 2000; Avcı \& Yüksel, 2011) gibi sosyal becerileri kazandırmaktadır.

Okuma çemberi, ilköğretim üçüncü sınıftan başlamak üzere tüm eğitim düzeylerinde ve tüm derslerde kullanılabilir fakat çoğunlukla, Türkçe, edebiyat gibi anadili dersleriyle yabancı dil öğretiminde kullanılmaktadır (Knowles \& Smith, 2003). Yaygın eğitim kapsamında da en çok yabancı dil öğreten kurslar tercih etmektedir (Furr, 2003). Fen bilgisi, coğrafya, tarih gibi derslerde de kullanımına ilişkin çalışmalar bulunmaktadır (Knowles \& Smith, 2003). Yöntem, ilköğretim ilk kademede kitap okumayı daha verimli hâle getirmede de kullanılabilir (Avcı \& Yüksel, 2011).

Okuma çemberinin öğrenciler üzerine etkisine ilişkin Türkiye'de, Avcı ve Yüksel (2011) tarafından yapılmış tek bir çalışma bulunmaktadır. Bu çalışma, ilkokul üçüncü sınıf öğrencileri ile yürütülmüş, araştırma yöntemi olarak örnek olaydan faydalanılmıştır. Avcı ve Yüksel (2011) tarafından yapılan çalışmada okuma çemberinin okuduğunu anlama becerisi üzerine etkisini araştırmak için tek grup kullanılmıştır. Oysa okuma çemberinin okuduğunu anlama üzerine etkisini net bir biçimde ortaya koymak için deneysel bir çalışmaya ihtiyaç söz konusudur. Bu çalışmada, okuma çemberinin okuduğunu anlama becerisi üzerine etkisini belirlemek amaciyla ön-test - son-test kontrol gruplu deneysel çalışmadan faydalanılmıştır. Elde edilen bulgular, okuma çemberini sınıfında uygulanmak isteyen öğretmenlere ve alanda çalışma yapacak akademisyenlere yol gösterici olacaktır.

$\mathrm{Bu}$ araştırmada, okuma çemberinin ilköğretim beşinci sınıf öğrencilerinin okuduğunu anlama becerileri üzerine etkisinin incelenmesi amaçlanmıştır. Araştırmanın hipotezleri şöyledir:

1) Okuma çemberi, ilköğretim beşinci sınıf öğrencilerinin okuduğunu anlama becerisini geliştirmektedir.

2) Okuma çemberi, okuduğunu anlama becerisi düşük olan ilköğretim beşinci sınıf öğrencilerinin okuduğunu anlama becerisini, yüksek olanlara göre daha fazla geliştirmektedir. 


\section{Yöntem}

\section{Araştırma Modeli}

$\mathrm{Bu}$ çalışmada, gerçek deneme modelleri arasında yer alan ön-test - son-test kontrol gruplu deneysel desen kullanılmıştır (Karasar, 2005). Araştırmada deneysel desenin gereği olarak (Büyüköztürk, 2007) yansız atama yöntemi ile biri deney, diğeri kontrol olmak üzere iki grup oluşturulmuştur. İki grupta da deney öncesinde ve sonrasında ölçümler yapılmıştır. Deney grubunda sınıf öğretmeni, ilkokul beşinci sınıf öğretim programına dayalı etkinliklere ek olarak okuma çemberi yöntemini uygulamıştır. Kontrol grubunun sınıf öğretmeni ise öğretim programına ek herhangi bir uygulama yapmamıştır. Hem deney hem de kontrol grubunda uygulama öncesinde ve sonrasında "Okuduğunu Anlama Ölçeği” uygulanmıştır.

\section{Denekler}

Araştırma, İstanbul ili Maltepe ilçesi sınırları içerisinde yer alan bir ilköğretim okulunun beşinci sınıf A ve B şubelerine devam eden öğrenciler ile yürütülmüştür. A şubesi deney grubu, B şubesi ise kontrol grubu olarak belirlenmiştir. Araştırma için öncelikle okul idaresinin onayı alınmıştır. Ardından uygulama için dördüncü ve beşinci sınıf öğretmenlerine okuma çemberi ve planlanan araştırma hakkında bilgi verilmiştir. Görüşülen sekiz öğretmenden 5-A şubesinin öğretmeni uygulamayı kabul etmiştir. Kontrol grubu ise dört beşinci sınıf öğretmeni ve okul idarecileriyle yapılan görüşme sonucunda deney grubu ile akademik başarı, öğrenci sayısı ve cinsiyet dağılımı açısından benzer özelliklere sahip olması nedeniyle tercih edilmiştir. Deney grubunda 34 öğrenci, kontrol grubunda ise 33 öğrenci bulunmaktadır. Deney ve kontrol grupları, Tablo 1'den de anlaşılabileceği gibi okuduğunu anlama becerisi açısından da birbirine benzemektedir ( $t=1.900, p>0.05)$.

Tablo 1

Deney ve Kontrol Gruplarının Okuduğunu Anlama Testi Ön Test Puanlarının Karşılaştırılmasına Yönelik t Testi Sonuçları

\begin{tabular}{lccccc}
\hline \multicolumn{1}{c}{ Grup } & $n$ & $X$ & $S S$ & $t$ & $p$ \\
\hline Deney & 34 & 10.9 & 4.5 & \multirow{2}{*}{1.900} & .062 \\
Kontrol & 33 & 12.7 & 3.5 & & \\
\hline
\end{tabular}

Son teste deney grubundan üç öğrenci, kontrol grubundan ise sekiz öğrenci katılmamıştır. $\mathrm{Bu}$ durum son testin eğitim-öğretim döneminin son haftasında uygulanmasından kaynaklanmıştır. Karşılaştırmalı istatistiksel analizler için deney grubundan 31 öğrencinin, kontrol grubundan ise 25 öğrencinin verileri kullanılmıștır. 


\section{Veri Toplama Aracı}

$\mathrm{Bu}$ çalışmada araştırmanın amacı doğrultusunda veri toplamak amacıyla “Okuduğunu Anlama Testi” kullanılmıştır. Test, Erginer (1999) tarafından geliştirilmiştir. Testte okuduğunu anlama becerisini ölçmeye yönelik 20 soru yer almaktadır. Sorular, metne başlık bulma, metindeki kahramanları bulma, metinde geçen kelimenin eş anlamlısını bulma, anlamı bozan kelimeyi bulma gibi okuduğunu anlamaya yönelik becerileri ölçmektedir. Testten alınabilecek en düşük puan “0”, en yüksek puan ise 20'dir. Testin geçerlik ve güvenirlik çalışmaları 146 üçüncü, dördüncü ve beşinci sınıf öğrencisi ile yapılmıştır. Bu uygulamada testi geliştirmek için madde güçlük ve madde ayırtedicilik indeksleri ile madde varyansları ve madde güvenirlikleri hesaplanmıştır. Testin ortalama güçlüğü .43 olup, ayırtedicilik değerleri .32 ile .80 arasındadır. Nihai test oluşturulduktan sonra KR-20 ile yapılmış güvenirlik analizinde .90 değerine ulaşılmıştır. Testin bu uygulama için belirlenen güvenirlik katsayısı ise .87 'dir.

\section{Deneysel İşlemler}

Yukarıda da açıklandığı gibi, deney grubunda okuma çemberi yöntemi uygulanmıştır. Uygulamanın ilk aşamasını, kitapların seçimi ve temini oluşturmuştur. Kitap seçiminde, yaş düzeyine uygunluk ve ilgi çekicilik şartları aranmıştır. Kitap seçimi, çocuk edebiyatı hakkında yeterli bilgiye sahip olması ve öğrencileri tanıması nedeniyle sınıf öğretmeni tarafından yapılmıştır. Kitaplar, öğrencilerin ilgilerinin farklı olacağı düşüncesiyle farklı konulardan seçilmiş ve konulara öğretmen karar vermiştir. Seçilen kitapların isimleri ve konuları; Ünlüler de Çocuktu (Biyografi), Çatalhöyük Öyküleri (Tarihi), On Beş Türk Masalı (Masal), Uzaylılar Geliyor (Bilimkurgu), Süper Futbolcular için Başlama Düdüğü Çalıyor (Spor), Gözlerinde Güneş Var (An1). Bu kitapların her birinden altı kitap alınmış olup, bu sayı sınıf mevcudunun 35 olması ve tekniğin özelliği gereği her grupta en fazla altı öğrenci bulunabilmesi nedeniyle tercih edilmiştir. Uygulamada ikinci işlem olarak, kitap okumaya başlanmadan bir hafta önce, ön-test uygulaması yapılmıştır. Uygulamanın üçüncü aşamasında yöntem uygulanmaya başlanmış, kitaplar önce öğrencilere öğretmen tarafından kısaca tanıtılmış ve öğrencilerden seçim yapmaları istenmiştir. Kitap seçimine göre beş tane altı kişilik, bir tane de beş kişilik grup oluşturulmuştur. Gruplar, aynı gün yaptıkları ilk toplantılarında, o aşamadan sonraki her toplantı için okuyacakları sayfa sayısına, kimlerin hangi görevleri hangi sırada yapacaklarına ve projenin türüne karar vermişlerdir. Öğretmenin de yönlendirmesiyle, her grup kitabını altı bölüme ayırmıştır. Bu işlemlerden sonra öğretmen, tekniğin gereği olarak üstlenilen rollerin neler olduğunu ve grup tartışmalarının nasıl yapılması gerektiğini öğrencilere anlatmak için küçük bir hikâye üzerinden uygulama yapmıştır. Bu uygulamada öğretmen hikâyeyi projeksiyonla tahtaya yansıtarak öğrencilerin okumasını sağlamış ve her grubun yapacağı işi bu hikâyeye bağlı olarak açıklamıştır. $\mathrm{Bu}$ işlemden sonra kitapların okunması ve tartışılması sürecine geçilmiştir. Öğrenciler her hafta pazartesi ve perşembe günleri bir ders saatinde grup toplantılarını yapmışlardır. Toplantılarda, öncelikle her öğrenci kendi görevleri kapsamında ürettiklerini arkadaşlarıyla paylaşmış, ardından grup okunan 
bölüm üzerinde tartışmıştır. Planlandığı şekliyle uygulama, haftada iki gün olmak üzere üç hafta sürmüştür. Dördüncü hafta gruplar farklı projelerle üç ders saati içerisinde kitaplarını sınıfa sunmuşlardır. Proje olarak bir grup kukla tiyatrosunu, bir grup şiir yazmay1, bir grup PowerPoint sunumunu, bir grup görsel sunumu, iki grup ise rol oynamayı seçmiştir. Grup sunumlarının olduğu günden bir hafta sonra son-test uygulanmış ve çalışma sonlandırılmıştır.

Kontrol grubunda ise sınıf öğretmeni, ilköğretim beşinci sınıf öğretim programı çerçevesinde önceden planlamış olduğu etkinlikler dışında herhangi bir kitap okuma çalışması yürütmemiştir.

\section{Uygulama Süreci}

Araştırma, 2010-2011 eğitim-öğretim yılı güz yarıyılında, Kasım, Aralık ve Ocak aylarında gerçekleştirilmiştir. Kasım ayında öğretmene hizmet içi eğitim, kitapların seçilmesi ve temin edilmesi işlemleri gerçekleştirilmiştir. Deneysel uygulama başlamadan bir hafta önce ise deney ve kontrol gruplarına Okuduğunu Anlama Testi, sınıf öğretmenleri tarafindan ders saati içerinde ön-test olarak uygulanmıştır. Bu uygulamadan sonra, ilk deneysel işlem haftasında (salı günü) öğretmen, gruplara tekniği anlatmış ve kitaplarını seçtirmiştir. Yine ilk gün, gruplar da ilk toplantılarını yapmışlardır. İlk haftanın perşembe günü gruplar önceden belirledikleri sayfa aralıklarını okumuşlar ve tartışmışlardır. Bundan sonraki haftalarda gruplar, haftada iki defa olmak üzere beş toplantı daha yapmışlardır. Dördüncü haftanın perşembe günü gruplar okudukları kitapları seçtikleri projelerle sınıf arkadaşlarına sunmuşlardır. Deneysel işlemin bitmesinden bir hafta sonra, Okuduğunu Anlama Testi son-test olarak uygulanmıştır. Son test, sömestr tatilinden bir hafta önce uygulanmıştır.

\section{Verilerin Analizi}

Okuduğunu Anlama Ölçeği ile elde edilen veriler, SPSS programı kullanılarak analiz edilmiştir. "Okuduğunu Anlama Ölçeği”nin deneyden önceki uygulamasında deney ve kontrol grupları arasında fark olup olmadığını anlamak için bağımsız gruplar $t$ testi uygulanmıştır. Her iki grupta, deney öncesi ve sonrası değişimleri test etmek için Wilcoxon İşaretli Sıralar Testi kullanılmıştır. Bu test, grup test puanlarının iki yönlü ANOVA testinin ön koşullarını sağlamaması ve grup sayılarının kritik sınırda $(N=30$ sınırında) olması nedeniyle tercih edilmiştir. Ayrıca, yöntemin etkisini net bir biçimde anlamak amacıyla deney grubu, “Okuduğunu Anlama Testi”nden aldıkları puanlara göre düşük ve yüksek beceri düzeyine sahip olanlar şeklinde iki gruba ayrılmıştır. Öntestten 0-10 puan alanlar alt, 11-20 puan alanlar üst beceri grubu olarak adlandırılmıştır. $\mathrm{Bu}$ grupların ön-teste göre son-testteki değişimlerinin test edilmesinde Wilcoxon İşaretli Sıralar Testi uygulanmıştır.

\section{Bulgular}

Yukarıda da açıklandığı gibi bu çalışmada "Okuma çemberinin ilköğretim beşinci sınıf öğrencilerinin okuduğunu anlama becerilerine etkisinin incelenmesi" amaçlanmış, "Okuma çemberi ilköğretim beşinci sınıf öğrencilerinin okuduğunu anlama 
becerisini geliştirmektedir” ve “Okuma çemberi, okuduğunu anlama becerisi düşük olan ilköğretim beşinci sınıf öğrencilerinin okuduğunu anlama becerisini, yüksek olanlara göre daha fazla geliştirmektedir" şeklinde iki araştırma hipotezi sınanmıştır. Çalışmanın amacı doğrultusunda, öğrencilerin okuduğunu anlama becerileri, "Okuduğunu Anlama Testi” ile ölçülmüştür.

Araştırmanın “Okuma çemberi, ilköğretim beşinci sınıf öğrencilerinin okuduğunu anlama becerisini geliştirmektedir" şeklinde ifade edilen birinci hipotezini test etmek amacıyla "Okuduğunu Anlama Testi”nin deney ve kontrol grupları için öntest ve son-test uygulanması sonucu elde edilen bulgulara Tablo 2, 3 ve 4'te yer verilmiştir. Tablo 2'de deney ve kontrol grupları için ön-test ve son-test uygulamalarından elde edilen bulgulara ilişkin betimleyici istatistik sonuçları yer almaktadir.

Tablo 2

Deney ve Kontrol Gruplarının Okuduğunu Anlama Testi Ön ve Son Test Puanları

\begin{tabular}{lcccccc}
\hline & \multicolumn{3}{c}{ Ön Test } & \multicolumn{3}{c}{ Son Test } \\
\hline \multicolumn{1}{c}{ Gruplar } & Ortalama & $\begin{array}{c}\text { Standart } \\
\text { Sapma }\end{array}$ & Ortanca & Ortalama & $\begin{array}{c}\text { Standart } \\
\text { Sapma }\end{array}$ & Ortanca \\
\hline Deney & 10.9 & 4.5 & 11.0 & 11.9 & 4.0 & 12 \\
Kontrol & 12.7 & 3.5 & 13.0 & 13.5 & 2.4 & 13.5 \\
\hline
\end{tabular}

Tablo 3’te deney grubu için ön-test ve son-test uygulamalarından elde edilen bulgulara ilişkin Wilcoxon İşaretli Sıralar Testi sonuçları yer almaktadır.

Tablo 3

Deney Grubu İçin Deney Öncesi ve Sonrası Okuduğunu Anlama Testi Puanlarının Wilcoxon Issaretli Stralar Testi ile Analiz Sonuçları

\begin{tabular}{cccccc}
\hline Son Test-Ön Test & $\mathrm{n}$ & Sıra Ortalaması & Sıra Toplamı & $\mathrm{z}$ & $\mathrm{P}$ \\
\hline Negatif Sıra & 7 & 12.86 & 90 & & \\
Pozitif Sıra & 19 & 13.74 & 261 & 2.191 & .028 \\
Eşit & 5 & - & - & & \\
\hline
\end{tabular}

Tablo 3'te yer alan bulgulara göre, deney grubunda yer alan öğrencilerin okuduğunu anlama testinden aldıkları deney öncesi ve sonrası puanları arasında anlamlı bir fark bulunmaktadır $(Z=2.191, p<0.05)$. Fark puanlarının sira ortalamaları ve sira toplamları dikkate alındığında, gözlenen bu farkın pozitif sıralar, yani son test puanı lehine olduğu görülmektedir. Buradan hareketle deney grubunun okuduğunu anlama becerilerinde deney öncesine göre deney sonrasında belirgin bir biçimde geliştiği söylenebilir. 
Tablo 4'te kontrol grubu için ön-test ve son-test uygulamalarından elde edilen bulgulara ilişkin Wilcoxon İşaretli Sıralar Testi sonuçları yer almaktadır.

Tablo 4

Kontrol Grubu İçin Deney Öncesi ve Sonrası Okuduğunu Anlama Testi Puanlarının Wilcoxon Işsaretli Siralar ile Analiz Testi Sonuçları

\begin{tabular}{cccccc}
\hline Son Test-Ön Test & $\mathbf{n}$ & Sıra Ortalaması & Sıra Toplamı & z & P \\
\hline Negatif Sıra & 9 & 6.17 & 55.50 & & .513 \\
Pozitif Sıra & 7 & 11.50 & 80.50 & & \\
Eşit & 8 & - & - & \\
\hline
\end{tabular}

Tablo 4'te yer alan bulgulara göre, kontrol grubunda yer alan öğrencilerin okuduğunu anlama testinden aldıkları deney öncesi ve sonrası puanları arasında anlamlı bir fark bulunmamaktadır $(Z=0.654, p>0.05)$. Bu sonuca göre, normal öğretim programı uygulanan kontrol grubu öğrencilerinde okuduğunu anlama becerileri anlamlı gelişmemiştir. Elde edilen sonuç, okuma çemberinin okuduğunu anlama becerisi üzerindeki etkisini desteklemektedir.

Tablo 2, 3 ve 4’te yer alan bulgulara göre, “Okuma çemberi, ilköğretim beşinci sınıf öğrencilerinin okuduğunu anlama becerisini geliştirmektedir” hipotezi kabul edilmektedir. Buradan hareketle, okuma çemberi tekniğine göre kitap okumanın ilkokul beşinci sınıf öğrencilerinin okuduğunu anlama becerisini geliştirmede önemli etkisinin olduğu söylenebilir.

Tablo 5, 6 ve 7'de deney grubunun okuduğunu anlama becerisi açısından alt ve üst gruplarda yer alan öğrencilerin ön-test ve son-testten elde ettikleri puanların karşılaştırılmasına ilişkin bulgular yer almaktadır. Yöntem bölümünde de açıklandı̆̆ 1 gibi ön-testten 0-10 puan alanlar alt, 11-20 puan alanlar üst beceri grubu olarak adlandırılmıştır. Tablo 5'te, deney grubunun alt ve üst beceri gruplarına için ön-test ve son-test uygulamalarından elde edilen bulgulara ilişkin betimleyici istatistik sonuçları yer almaktadır.

Tablo 5

Deney Grubunun Alt ve Üst Beceri Gruplarının Okuduğunu Anlama Testi Ön ve SonTest Puanlart

\begin{tabular}{lcccccc}
\hline & \multicolumn{3}{c}{ Ön Test } & \multicolumn{3}{c}{ Son Test } \\
\hline \multirow{2}{*}{ Gruplar } & Ortalama & $\begin{array}{c}\text { Standart } \\
\text { Sapma }\end{array}$ & Ortanca & Ortalama & $\begin{array}{c}\text { Standart } \\
\text { Sapma }\end{array}$ & Ortanca \\
\hline Alt & 6.5 & 3.1 & 6.0 & 8.7 & 3.0 & 8.5 \\
Üst & 13.9 & 2.2 & 14.0 & 13.9 & 3.0 & 14.0 \\
\hline
\end{tabular}


Tablo 6'da okuduğunu anlama açısından alt beceri için ön-test ve son-test uygulamalarından elde edilen bulgulara ilişkin Wilcoxon İşaretli Sıralar Testi sonuçları yer almaktadir.

\section{Tablo 6}

Alt Beceri Grubu İçin Deney Öncesi ve Sonrası Okuduğunu Anlama Testi Puanlarının Wilcoxon Issaretli Siralar Testi ile Analiz Sonuçları

\begin{tabular}{lccccc}
\hline Son Test-Ön Test & $\mathrm{N}$ & Sıra Ortalaması & Sira Toplamı & $\mathrm{z}$ & $\mathrm{P}$ \\
\hline Negatif Sıra & 0 & .00 & .00 & & \\
Pozitif Sıra & 10 & 5.50 & 55.00 & 2.814 & .005 \\
Eşit & 2 & - & - & & \\
\hline
\end{tabular}

Tablo 6’da yer alan bulgulara göre, alt beceri grubunda yer alan öğrencilerin okuduğunu anlama testinden aldıkları deney öncesi ve sonrası puanları arasında anlamlı bir fark bulunmaktadır $(Z=2.814, p<0.05)$. Fark puanlarının sira ortalamaları ve sira toplamları dikkate alındığında, gözlenen bu farkın pozitif sıralar, yani son-test puanı lehine olduğu görülmektedir. Buna göre okuma çemberinin okuduğunu anlama becerisi düşük olan öğrencilerin bu becerilerinin geliştirilmesinde etkili olduğu söylenebilir.

Tablo 7'de okuduğunu anlama açısından üst beceri için ön-test ve son-test uygulamalarından elde edilen bulgulara ilişkin Wilcoxon İşaretli Sıralar Testi sonuçları yer almaktadır.

Tablo 7

Üst Beceri Grubu İçin Deney Öncesi ve Sonrası Okuduğunu Anlama Testi Puanlarının Wilcoxon Işaretli Stralar Testi Sonuçları

\begin{tabular}{lccccc}
\hline \multicolumn{1}{c}{ Son Test-Ön Test } & $\mathrm{n}$ & Sıra Ortalaması & Sıra Toplamı & $\mathrm{z}$ & $\mathrm{P}$ \\
\hline Negatif Sıra & 7 & 9.00 & 63.00 & & \\
Pozitif Sıra & 9 & 8.11 & 73.00 & .263 & .793 \\
Eşit & 3 & - & - & & \\
\hline
\end{tabular}

Tablo 7'de yer alan bulgulara göre, üst beceri grubunda yer alan öğrencilerin okuduğunu anlama testinden aldıkları deney öncesi ve sonrası puanları arasında anlamlı bir fark bulunmamaktadır $(Z=0.263, p>0.05)$. Bu bulguya göre okuma çemberi, okuduğunu anlama becerisi yüksek öğrencilerin bu becerilerinin geliştirilmesinde bir etkiye sahip değildir. Bu sonuca göre, "Okuma çemberi, okuduğunu anlama becerisi düşük olan ilköğretim beşinci sınıf öğrencilerinin okuduğunu anlama becerisini, yüksek olanlara göre daha fazla geliştirmektedir” hipotezi kabul edilmektedir. Yine bu sonuçtan hareketle Tablo 3’teki anlamlı farkın düşük beceri grubundan kaynaklandığı da söylenebilir. 


\section{Sonuç ve Tartışma}

Okuduğunu anlama, okunan metnin anlamını bulma, bunun üzerinde düşünme ve çıkarımlarda bulunmadır (Güneş, 2004). Bireylerde farklı derecelerde bulunan okuduğunu anlama becerisi, üzerinde çalışma ile geliştirilebilir bir nitelik taşımaktadır. Bireyin okuduğunu anlama becerisi, dikkat, hafızayı kullanma, mantıksal çıkarım yapabilme yetenekleri, kitabı okuma nedeni, konuya duyulan ilgi, özyeterlik algısı, kelime haznesi, dilin kurallarına hâkimiyet ve konuyla ilgili önbilgi gibi değişkenlerden etkilenir. Birey okumaya başladığında bu becerilerin birçoğunda gelişme olur. Örneğin; kelime haznesi genişler, alan bilgisi artar, okuma hızı artar. Kitabın özelliğine göre de konuya duyulan ilgi ve kendilik algısında artış olur. Okumaya yönelik motivasyon da okuduğunu anlamada önemlidir. Bireyin ilgisini çeken metinler, okuduğunu anlama üzerinde olumlu etkiye sahiptir (Snow, 2002).

Okuma çemberi, ayrıntılı okumayı, farklı görevlerin yerine getirilmesini, bölüm tartışmaları aracılığıyla öğrencinin konu üzerinde düşünmesini ve değerlendirme yaparak kendi çıkarımlarına varmasını sağlamaktadır. Bu etkilerinin bir sonucu olarak da okuma çemberi, okuduğunu anlama becerisini geliştirmektedir. Okuma çemberinin okuduğunu anlama üzerine etkisi birçok araştırmanın bulguları ile desteklenmektedir. Mizerka (1999) tarafindan beşinci sınıflar, Olsen (2007) tarafindan dokuzuncu sınıflar, Camp (2006) tarafindan on birinci sınıflar, Briggs (2010) tarafindan üçüncü sınıflar ile Avcı ve Yüksel (2011) tarafından dördüncü sınıflar ile yapılan araştırmalarda okuma çemberinin öğrencilerin okuduğunu anlama becerisini geliştirdiği tespit edilmiştir. Bu çalışmada da, okuma çemberi, daha önce yapılan benzer araştırmalara paralel olarak öğrencilerin okuduğunu anlama becerilerini geliştirmiştir. Okuma çemberinde, bireysel kitap okumalardan farklı olarak, öğrenciler kitabı sürece yayılmış bir şekilde, derinlemesine okumakta ve anladıklarını arkadaşlarıyla paylaşmaktadır. Paylaşımın yapıldığı toplantılarda, her öğrencinin diğer arkadaşlarının okudukları bölümlerden çıkardığı anlamları da öğrenme firsatı bulunmaktadır çünkü okuyucu tepkisi teorisine (Rosenblatt, 1978) göre, öğrenciler kitabı kendi yaşantısına göre anlamlandırdıklarından okudukları kitaptan farklı şeyler anlamakta ve kazanmaktadır (Aktaran: Tracey \& Morrow, 2006). Bunun yanında öğrencinin aldığı görevin özelliğine göre farklı kaynaklardan araştırma yapması gerekmektedir. Örneğin; bağ kurucunun görevi, kitapta geçen olayı günlük hayatla, tarihi olaylarla vb. ilişkilendirmektir. Bu görev öğrenciyi yeni bilgiler edinmeye yönlendirmektedir. Buradan hareketle okuma çemberi ile kitap okuyan öğrencinin, kitabı derinlemesine anlayarak okumaya çalışması, ödevi için araştırma yapması, bulgularını yazılı hâle getirmesi, bunu arkadaşlarıyla paylaşması gibi nedenlerle okuduğunu anlama becerisinin geliştiği söylenebilir. $\mathrm{Bu}$ araştırma kapsamında sadece bir kitabın okunması ve öğrencilerin okuduğunu anlama becerisinin bu sayede gelişmesi de tekniğin etkililiğine bir kanıt olarak gösterilebilir.

Araştırma bulgularına göre, okuma çemberinin öğrencilerin okuduğunu anlama becerisini geliştirme yönündeki etkisi, bu beceri yönünden yeteneği az olan öğrenciler üzerinde daha fazladır. Mizerka (1999) ile Blum ve diğerleri (2002) tarafindan yapılan çalışmalarda, bu araştırmanın bulgularına benzer şekilde, öğrenme güçlüğü çeken 
öğrencilerin okuma çemberi uygulamasından daha fazla fayda sağladığı tespit edilmiştir. Yine, Avcı ve Yüksel (2011) tarafından yapılan çalışmada da okuma çemberinin okuduğunu anlama becerisi düşük öğrenciler üzerinde daha etkili olduğu tespit edilmiştir. Bu bulgulara göre, okuduğunu anlama becerisi düşük öğrencilerin okuma çemberinden daha fazla fayda sağladığı düşünülebilir. Araştırma kapsamında uygulanan test ile ölçülen okuduğunu anlama becerisi yüksek olan öğrencilerin, becerilerinde bir artış olmamıştır fakat bu sonuçtan okuma çemberinin bu öğrencilere hiçbir etkisinin olmadığı çıkarılmamalıdır. Oysa az kitap okuma, kitap okumayı sevmeme, bilişsel yetenek açısından düşük olma gibi nedenlerle okuduğunu anlama becerisi düşük olan öğrencilerin, bu yöntem sayesince becerilerinde belirgin bir biçimde gelişme olması oldukça kayda değer bir bulgudur. Yöntemin sürekli kullanılması durumunda, okuduğunu anlama becerisi açısından düşük yeteneğe sahip öğrencilerin yüksek yeteneğe sahip olanların düzeyine ulaşabileceği söylenebilir.

Deney sürecinde ön-test ve son-test uygulamaları arasında 45 günlük bir süreç geçmiştir. $\mathrm{Bu}$ süreçte normal öğretim programını uygulayan kontrol grubunun okuduğunu anlama becerisi benzer kalmıştır. Buradan hareketle, ilkokul beşinci sınıf programının okuduğunu anlama becerisini sağlama açısından tam olarak faydalı olmadığı sonucuna varılabilir. Okuduğunu anlama, akademik bilgi edinmeyi sağlayan temel bilişsel becerilerden biri olduğundan, bu beceri açısından yetersiz olan bir öğrencinin, matematik, fen, sosyal bilgiler gibi temel derslerin konularını öğrenmesinde sorun olacaktır.

Sonuç olarak, araştırmaya göre okuma çemberinin, okuduğunu anlama becerisi düşük olan ilköğretim beşinci sınıf öğrencilerinde bu beceriyi kazandırmak veya geliştirmek için kullanılabileceği söylenebilir. Bundan sonra yapılacak çalışmalarda, okuma çemberinin ilkokul üçüncü sınıftan lise son sınıfa kadar örgün eğitimin farklı kademelerinde, üniversitelerde ve yetişkin eğitimlerinde uygulanabilirliğine ilişkin araştırmalar yapılabilir. Bu çalışmada herhangi bir derse bağlı olmadan öğrenciler sadece ilgilerine göre seçtikleri kitapları okumuşlardır. Okuma çemberinin derslerde akademik bilgi ediniminde kullanımına ilişkin örnek çalışmaların yapılmasına da ihtiyaç duyulmaktadır. Bunun yanında okuma çemberinin okuduğunu anlamaya, derse ve kitap okumaya yönelik ilgiye etkisinin daha net bir biçimde anlaşılması için okuma çemberinin farklı kitap okuma teknikleriyle karşılaştırılması gerekir.

\section{Kaynakça}

Alwood, C. S. (2000). Exploring the role of the teacher in student-led literature circle (Research Report ). Retrieved from ERIC database. (ED 442748)

Avc1, S., \& Yüksel, A. (2011). Okuma çemberi yöntemine göre kitap okumanın öğrencilere bilişsel ve duyuşsal katkıları. Kuram ve Uygulamada Ĕ̆itim Bilimleri, 3(11), 1285-1300.

Blum, H. T., Lipsett, L. R., \& Yocom, D. J. (2002). Literature circles: A tool for self determination in one middle school inclusive classroom. Remedial and Special Education, 23(2), 99-108. 
Brabham, E. G., \& Villaume S.K. (2000). Questions and answers: Continuing conversations about literature circles. The Reading Teacher, 54(3), 278-280.

Briggs, S. R. (2010). Using literature circles to increase reading comprehension in third grade elementary students (Unpublished master's thesis). Dominican University of California, San Rafael, California.

Burda, K. (2000). Living and learning: A four-year journey into literature circles. Primary Voices K-6, 9(1), 17-22.

Büyüköztürk, Ş. (2007). Deneysel desenler. Ankara: PegemA Yayınc1lık.

Camp, C. S. (2006). The effect of literature circles vs. sustained silent reading (SSR) among eleventh grade English students. Masters Abstracts International, 46(03), 41-1219.

Carpinelli, T. (2006). Literature circles: A Collaborative success story! Library Media Connection, 25(3), 32-33.

Chiang, M., \& Huang, C. (2005). The effectiveness of literature circles in EFL setting: A classroom investigation. The Proceedings of 2005 International Conference and Workshop on TEFL \& Applied Linguistics, Taipei, Taiwan.

Culli, L. M. (2002). Investigation of literature circles in the middle school language art classroom (Unpublished master's thesis). Chapman University, Orange, California.

DaLie, S. O. (2001). Students becoming real readers: Literature circles in high school English classes. In B. O. Ericson (Ed.), Teaching reading in high school English classes (pp. 84-100). Urbana, IL: NCTE.

Daniels, H. (1994). Literature circles: Voice and choice in book clubs and reading groups. Portland, ME: Stenhouse.

Daniels, H. (2002). Literature Circles: Voice and choice in book clubs and reading groups (2nd ed.). Portland, ME: Stenhouse.

Daniels, H. (2003). How can you grade literature circles? Voices From the Middle, 11(1), 52-53.

Erginer, E. (1999). İlköğretim 3, 4 ve 5. sinıf öğrencilerinin okuduğunu anlama becerilerinin değerlendirilmesi. Pamukkale Üniversitesi Eğitim Fakültesi Dergisi, 6, 1-11.

Furr, M. (2003). Why and how to use EFL literature circles. Retrieved from http://www.eflliteraturecircles.com /howandwhylit.pdf

Güneş, F. (2004). Okuma yazma ögretimi ve beyin teknolojisi. Ankara: Ocak Yayınları.

Hsu, J. T. (2004). Reading together: Student teacher meet in literature circles. Paper presented at the National Conference on English Teaching and Learning, Huwei, Taiwan. Retrieved from ERIC database. (ED 493021)

Karasar, N. (2005). Bilimsel araştırma yöntemi. Ankara: Nobel Yayın Dağıtım.

Knowles, E., \& Smith, M. (2003). Talk about books! A guide for book clubs, literature circles, and discussion groups, grades 4-8. Westport, CT: Libraries Unlimited. 
Mizerka, P. M. (1999). The impact of teacher directed literature circles versus studentdirected literature circles on reading comprehension at the sixth-grade level (Unpublished doctoral dissertation). University of Illinois, IL.

Moeller, V. J., \& Moeller, M. V. (2007). Literature circles that engage middle and high school students. Larcmont, NY: Eye on Education.

Neamen, M., \& Strong, M. (2001). More literature circles: Cooperative learning for grades 3-8. Englewood, Colorado: Libraries Unlimited.

Olsen, A. S. W. (2007). Literature circles and ninth grade students: A student-centered approach to reading (Unpublished master's thesis). Southwest Minnesota State University, Marshall, MN.

Pitton, D. E. (2005). Lit circles, collaboration and student interest. Academic Exchange Quartely, 9(4), 84-90.

Rutherford, A., Carter, L., Hillmer, T., Kramer, M., \& Parker, A. (2009). Promoting intrinsic reading: Implementing literature circles with intermediate-grade students and preservice teachers. The International Journal of the Book, 6(4), 43-49.

Short, K., Kaufman, G., Kaser, S., Kahn, L. H., \& Crawford, K. M. (1999). "Teacherwatching": Examining teacher talk in literature circles. Language Arts, 76(5), 377385 .

Snow, C. E. (2002). Reading for understanding: Toward a research and dvelopment program in reading comprehension. Santa Monica, CA: Rand Corporation.

Stabile, C. (2009). Are literature circles an effective reading strategy for struggling readers? (Unpublished master's thesis). Ohio University, Athens, $\mathrm{OH}$.

Straits, W. (2007). A literature circles approach to understanding science as a human endeavor. Science Scope, 31(2), 32-36.

Tomlinson, C. A., \& Strickland, C. A. (2005). Differentiation in practice: A resource guide for differentiating curriculum. Alexandria, VA: The Association for Supervision and Curriculum Development.

Tracey, D., \& Morrow, L. M. (2006). Lenses on reading: An introduction to theories and models. New York: Guilford Press. 